DOI https://doi.org/10.18551/rjoas.2018-06.39

\title{
BUSINESS DEVELOPMENT STRATEGY OF STOCK FARMER COOPERATIVE OF SOUTH BANDUNG PANGALENGAN
}

\author{
Anggreny Chressya Clara* \\ Master Program on Business Management, Bogor Agricultural University, Indonesia
}

Asmara Alla, Purnamadewi Yeti Lis, Lecturers

Master Program on Business Management, Bogor Agricultural University, Indonesia

\author{
*E-mail: chressya clara@yahoo.com \\ ORCID: 0000-0002-2023-618X
}

\begin{abstract}
The purposes of this research are to identify and review internal and external factors in KPBS Pangalengan and to develop alternative strategies and priority strategies for business development in KPBS Pangalengan. Porter's value chain approach was used to analyze internal factors and PEST approach was used to analyze external factors. The method used in this research is descriptive analysis. Analyzers used in this research are SWOT matrix and combination of Analytic Hierarchy Process. The result of the sequence of strategies leads to business development that is by inviting the investors to make investment in KPBS and building alliances with more Milk Processing Industry. Both strategies will motivate the stock farmers to be more enthusiastic in the maintenance process until the production process. Thus, it can improve the competitiveness of the stock farmers. After performing these two strategies, KPBS can run the following four strategies: conducting periodic discussions among stakeholders, creating human resources training and development, conducting integrated supervision, optimizing milk processing units, and resuming expansion strategy by cooperating with franchise stores and e-commerce.
\end{abstract}

\section{KEY WORDS}

Development strategy, milk cooperative, PEST analysis, SWOT, value chain.

The development of dairy industry in Indonesia that has been stagnant in the last 10 years indicates that dairy cattle business is no longer an economically promising business. It can be seen from the decline in national milk production that becomes a trend, (Morey, 2011). The slow development of milk production is influenced by several factors including: most of fresh milk producers is lower class society where the scale of their dairy cattle ownership is still low i.e. 3-5 cows, the management of livestock business is still low resulting in low resources of stock farmers, limited forage that has good quality, lack of expertise to help the stock farmers, low quality of the milk produced, high transportation costs due to inadequate infrastructure, low milk consumption of Indonesian society (Boediyana 2008).

According to Sirait (2009), an organization that directly deals with the development of dairy cattle business and resonates with the needs and development of national cow milk production is cooperative. Basically, the cooperative will make stock farmers more benefited in selling the milk because of the guarantee of a more stable market prices and in addition, the stock farmers get direct technical coaching by the cooperative (Mubyarto et al, 2014). Asmara et al (2016) stated that milk producer cooperative has the potential to strengthen competitiveness because of its potential to achieve economies of scale, minimize transaction costs, and increase barganing positions in pricing decision.

Based on the number of KPBS members obtained from the 2012-2016 report book (Table 1), there was a downward trend in the number of members each year with a percentage of non-active members averaging above $30 \%$. Thus, it raises the opinion on the commitment inconsistency of the cooperative members to the system that has been made 
before. The low entrepreneurial motivation will lead to loss of opportunity and low innovation that should be the basic power of the cooperative, (Douphrate et al, 2013).

Table 1 - Development of Total KPBS Members in 2012 - 2016

\begin{tabular}{llllll}
\hline Membership & 2012 & 2013 & 2014 & 2015 & 2016 \\
Active Member & 5031 & 3489 & 3145 & 3331 & 3184 \\
Non Active Member & 1340 & 2009 & 1905 & 1482 & 1501 \\
\hline TOTAL & 6371 & 5498 & 5050 & 4813 & 4685 \\
\hline
\end{tabular}

Source: Book of year-end meeting of KPBS 2012-2016.

Mandaka and Hutagaol (2016) argue that the high cost of production and management for livestock raising causes smallholder livestock farming tends to be less profitable than large and medium livestock farming business. In addition, the difficulty to meet the daily feed requirements is also an unresolved problem where limited land for feeding is also inadequate. It is also mentioned by Anggraeni (2012) that the planting of forage and the availabity of the labor have a positive effect on milk production on large livestock farming business.

Based on the financial report of KPBS in 2014-2016, Table 2 shows the growth of cooperative profit that tends to fluctuate. In 2014-2015, KPBS experienced a sharp decline, namely a decrease in profit of $2.40 \%$ and a turnover of $8.7 \%$. The fluctuation indicates that the performance of the cooperative effort is not maximal. Business units that affect the fluctuation are the business units of production, dairy processing, and forage factory. The problems of production and processing units are related to the price of milk purchased by IPS which is certainly influenced by milk quality and milk production of KPBS which tends to decrease. The KPBS party acknowledges a decrease in the amount of milk production. However, they also recognize the slow increase in milk quality. Livestock feed manufacturing units that produce and sell Complete Rations (CR) experience with the constraints of land availability to grow the feed crops, which also automatically decreases sales because the supply of feed crops doesnt met the requirement, (Dong, 2006). Thus, with the crucial problem above, KPBS really need to pay attention to both units because the two business units are the units that have an effect on the prosperity of KPBS members.

Table 2 - Profit, Total Asset, Earning, and the Growth of KPBS Profit in 2014-2016

\begin{tabular}{llll}
\hline Year & 2014 & 2015 & 2016 \\
\hline Profit & 1.224 .399 .686 & 1.265 .977 .984 & 1.361 .989 .969 \\
Total Asset & 24.122 .692 .517 & 24.907 .444 .553 & 25.926 .610 .338 \\
Earning & 229.114 .875 .045 & 209.260 .719 .453 & 243.689 .668 .281 \\
Profit Growth & $5.80 \%$ & $3.40 \%$ & $7.58 \%$ \\
\hline
\end{tabular}

The identified problems can be analyzed by finding the internal and external factors affecting the development of KPBS business. The SWOT method can be used to develop some alternative strategies. In addition, some priority strategies will be selected using the AHP method.

Research Problems. Based on the above background, the problems raised in this research are as follows: 1) how are the internal and external conditions of KPBS Pangalengan?, 2) what alternative strategies play a role in influencing business development of KPBS Pangalengan?, 3) what priority strategies can be applied in business development of KPBS Pangalengan?

Research Objectives. The objectives of this research are: 1) identifying the internal and external conditions of KPBS Pangalengan, 2) formulating the alternative strategies that influence business development of KPBS Pangalengan, 3) formulating priority strategies for business development of KPBS Pangalengan.

Significance of the Research. The findings of this research are expected to contribute to the development of dairy cooperatives in West Java and become a consideration for the policy that has been established before, be able to be a reference for business actors 
involved in making decisions, serve as one source of information and reference for further research, and become a means to develop insight and the ability to analyze problems related to business development.

Scope of the Research. This research is limited to the scope of discussion focusing on the management strengthening strategy of KPBS Pangalengan. The strategies existing in this research are limited to the setting stages of priority strategies. The implementation stage is fully handed over to the cooperative. The value chain discussed in this study is limited to dairy processing industry as the last consumer. Thus, it is not discussed in detail about the post-processing value chain by the related dairy industry.

\section{LITERATURE REVIEW}

KPBS implements agribusiness and agro-industry patterns in its service and business using pre-cultivation stage, cultivation process, cultivation marketing, and business support which are actualized by making business units. The number of business units in Pangalengan currently amounts to six units. The units are established based on their function and purpose in order to provide services to the community around Pangalengan. They consist of: Service Unit of Member Goods and Forage, Service Unit of Forage Company (PMT), Service Unit of Cattle Breeding and Forage Product, Service Unit of Production and Processing, Service Unit of Animal Health and Members, Service Unit of Transportation and Marketing.

Cooperative is an association of people who volunteer to meet the same needs and economic, social and cultural aspirations through democratically owned and supervised segregation (Hendrojogi 2007). The purpose of the cooperative is to maintain the suitability between identity, purpose, and environment. The cooperative should develop strategies to maintain and develop its market share and have the ability to provide some supplies based on the needs of its members and customers thoroughly (Kumar et al, 2013). namely:

According to David (2009), the strategic management process consists of three stages

- Formulation of the Strategy: this stage is an analysis of the internal and external environment to give an idea of the company's position in the competition so that the strengths, weaknesses, opportunities, and threats of the company can be known.

- Implementation of the Strategy: this stage involves the previous stages which then developed logically in the form of action.

- Evaluation of the Strategy: This is the final stage in the strategy management process where managers are needed to evaluate the strategy. Management evaluation is intended to improve and ensure the system within the company is running properly.

\section{METHODS OF RESEARCH}

Research Setting and Time. This research has been conducted in Pangalengan, Bandung for primary and secondary data collection. The study was conducted from September 2017 to December 2017.

Data Types, Sources, and Analysis. The data used in this research are primary and secondary data. Primary data was obtained from the first source by having depth inverview to the respondents using questionnaire. Respondents are expert sources selected based on consideration of expertise, practical experience, and stakeholders. Secondary data were obtained from various sources through literature studies, related institutions, as well as references from the internet. This data are the result of literature review, reports, documentation, archives, and others. This research has conducted various processing stages and data analysis as in Table 3 below.

Operational Thinking Framework. This research tries to formulate development strategies in Stock Farmer Cooperative of South Bandung (KPBS) Pangalengan. There are several stages in this research including: analyzing the internal conditions (Porter Value Chain Analysis) and external conditions (PEST Analysis). Analysis of internal and external 
environment is needed to know the current condition of milk cooperative in Bandung, namely knowing weakness and strengths, as well as opportunities and threats that must be faced by the cooperatives. SWOT matrix is used to see the factors influencing the internal and external consumptions of the cooperative. Prepare a strategy that will be created using AHP to prioritize the strategy. Schematic framework can be seen in Figure 1.

Table 3 - Processing Technique and Data Analysis

\begin{tabular}{|c|c|c|c|}
\hline No & Objectives & Analysis Tools & Output \\
\hline 1 & $\begin{array}{l}\text { The analysis of } \\
\text { internal and } \\
\text { external factors }\end{array}$ & $\begin{array}{l}\text { Internal: Porter value chain. (Main activities: logistics into, } \\
\text { operations, logistics out, marketing and sales, service. } \\
\text { Supporting activities: sales, technology development, } \\
\text { human resources, company infrastructure) } \\
\text { External: PEST Analysis (Political, Economic, Social, } \\
\text { Technological) }\end{array}$ & $\begin{array}{l}\text { To determine and map } \\
\text { KPBS's internal and } \\
\text { external conditions. }\end{array}$ \\
\hline 2 & $\begin{array}{l}\text { Formulation of } \\
\text { alternative strategy }\end{array}$ & SWOT & $\begin{array}{l}\text { Formulation of } \\
\text { alternative strategy }\end{array}$ \\
\hline 3 & Priority strategy & AHP (Software Expert Choice 2000) & Priority strategy \\
\hline
\end{tabular}

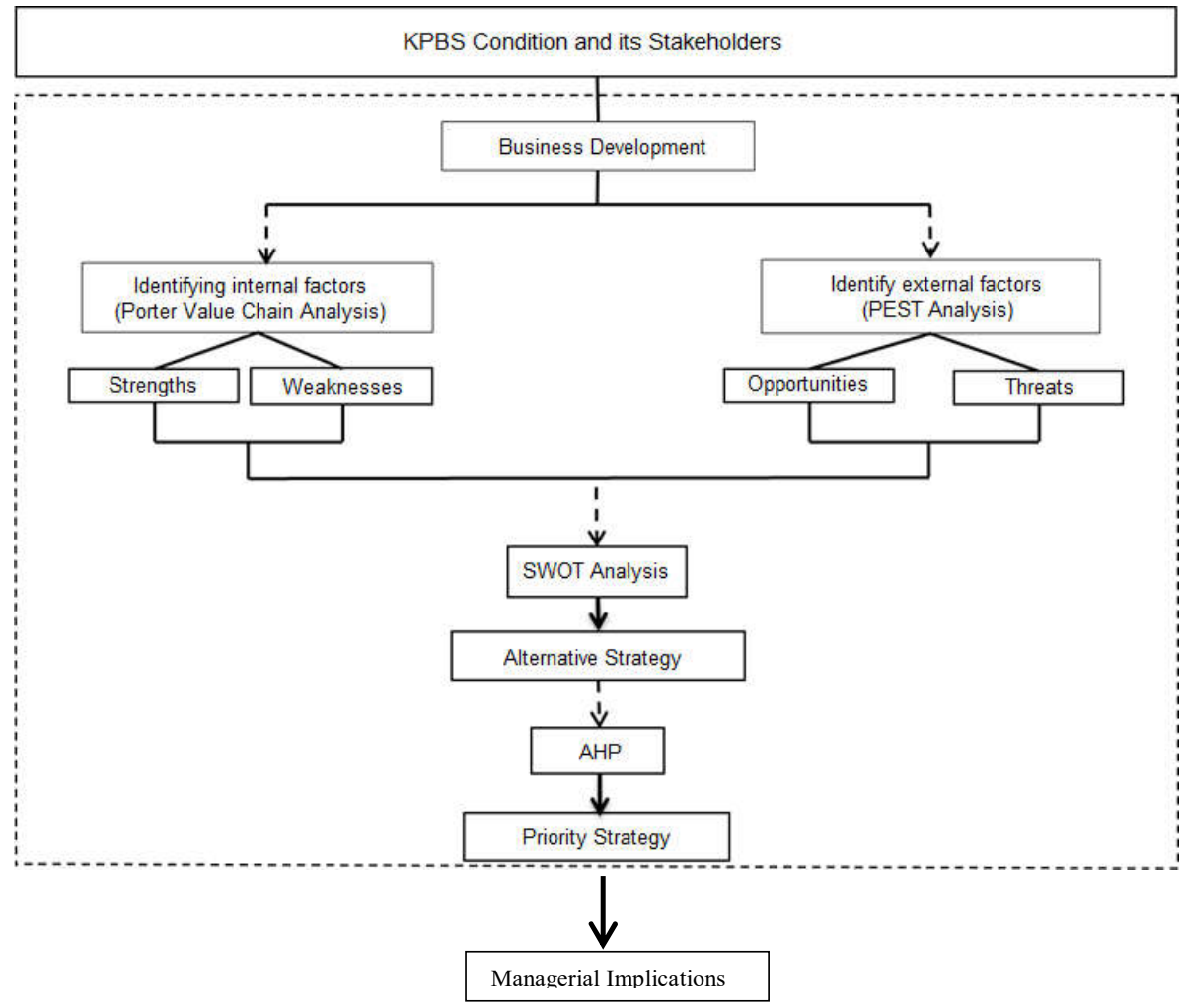

Figure 1 - Operational Thinking Framework

Note:

- Limitations of the Research - . . - -

- Process $\longrightarrow$

- Analysis tools - - - $\rightarrow$

\section{RESULTS AND DISCUSSION}

Analysis of Internal and External Environment. Porter value chain analysis can be viewed from two major activities, namely the main activities and supporting activities which are thoroughly influenced by nine indicators, namely logistics in, operational, logistics out, marketing and sales, service, purchasing, technology development, human resource 
management, and company's infrastructure. The results of value chain mapping can be seen in the following Table 4.

Table 4 - Mapping of Porter Value Chain

\begin{tabular}{|c|c|}
\hline \multicolumn{2}{|r|}{ Main Activities } \\
\hline Logistics in & $\begin{array}{l}\text { - The supply of fresh milk has not been sufficient for the market (W) } \\
\text { - } \quad \text { Handling of fresh milk to maintain its quality (W) } \\
\text { - } \quad \text { Limitations of the forage as raw material for Complete Rations (W) }\end{array}$ \\
\hline Operational & $\begin{array}{l}\text { - } \quad \text { Milk processing by Processing Unit into pasteurized milk and into milk derivative } \\
\text { products (yogurt, cheese, candy, milk crackers, mozarella) (S) } \\
\text { - } \quad \text { Simple product packaging (W) } \\
\text { - } \quad \text { Post-production milk storage in the storage (S) }\end{array}$ \\
\hline Logistics out & - Distribution of dairy products to several industries that have become partner. (W) \\
\hline $\begin{array}{l}\text { Marketing } \\
\text { Sales }\end{array}$ & $\begin{array}{l}\text { - } \quad \text { Brand image of KPBS that has been formed before }(\mathrm{S}) \\
\text { - } \quad \text { KPBS products are marketed to the Milk Processing Industry through job order (S) } \\
\text { - } \quad \text { KPBS milk is packed using papercup and prepack packaging (W) } \\
\text { - } \quad \text { KPBS sells Complete Rations for stock farmers (S) }\end{array}$ \\
\hline Services & $\begin{array}{l}\text { - } \quad \text { Service from PT BPR Unit owned by KPBS (S) } \\
\text { - } \quad \text { Product distribution service (S) }\end{array}$ \\
\hline & Supporting Activities \\
\hline $\begin{array}{l}\text { Purchase } \\
\text { Procurement }\end{array}$ & $\begin{array}{l}\text { - } \quad \text { Milk raw materials provided by stock farmers (W) } \\
\text { - } \quad \text { Supporting raw materials required in making products that are quite affordable (S) } \\
\text { - } \quad \text { The amount of transportation needs for the distribution of products (W) }\end{array}$ \\
\hline $\begin{array}{l}\text { Company's } \\
\text { Infrastructure }\end{array}$ & $\begin{array}{l}\text { - } \quad \text { Various tools used for milk production (S) } \\
\text { - } \quad \text { Adequate transportation and road access for milk distribution (S) } \\
\text { - } \quad \text { Land for forage owned by KPBS (S) }\end{array}$ \\
\hline Human Resources & $\begin{array}{l}\text { - } \quad \text { Lack of interest of the stock farmer as provider of fresh milk (W) } \\
\text { - } \quad \text { Lack of ability of human resources in processing and packing the milk (W) } \\
\text { - } \quad \text { Labor for distribution (W) } \\
\text { - The need for creativity and innovation for marketing human resources (W) }\end{array}$ \\
\hline $\begin{array}{l}\text { Technology } \\
\text { Development }\end{array}$ & $\begin{array}{l}\text { - The use of traditional technology }(\mathrm{W}) \\
\text { - } \quad \text { Manpower is still dominantly used in the process of making the products }(\mathrm{W})\end{array}$ \\
\hline
\end{tabular}

PEST Analysis. The external environment of the cooperative has the power that can cause adverse or beneficial influences for the cooperative. Positive influence will provide opportunities for cooperative to develop further whereas negative influence will make the cooperative difficult to develop. The result of PEST analysis is used to see how big the influence of environmental condition on KPBS development (Table 5).

Table 5 - PEST Analysis

\begin{tabular}{|c|c|}
\hline Politics & $\begin{array}{ll} & \text { Influence of Minister of Agriculture Regulation No. } 26 \text { of } 2017(\mathrm{O}) \\
\text { - } & \text { Government policies governing imports }(\mathrm{O}) \\
\text { - } \quad \text { The obligation of Milk Processing Industry to absorb domestic milk (O) }\end{array}$ \\
\hline Economy & $\begin{array}{ll}\text { - } & \text { International trade affecting the price of milk }(T) \\
\text { - } & \text { Distribution of dairy products made by the industry on a large scale }(T)\end{array}$ \\
\hline Social & $\begin{array}{l}\text { - The consumption of quality milk for current society is increasing }(O) \\
\text { - } \quad \text { E-business that provides easiness for people to buy the products }(O)\end{array}$ \\
\hline Technology & $\begin{array}{l}\text { - The development of animal husbandry technology }(\mathrm{O}) \\
\text { - } \quad \text { Lack of understanding in the processing of feed substitution }(\mathrm{T})\end{array}$ \\
\hline
\end{tabular}

Alternative Strategies for KPBS Business Development. The alternative strategy was obtained using SWOT analysis. Strengths, weaknesses, opportunities, and threats are determined based on the analysis on KPBS internal and external environments that have been described previously. The SWOT matrix will make it easier to see the alternative strategies affecting KPBS. 
Table 6 - SWOT Matrix

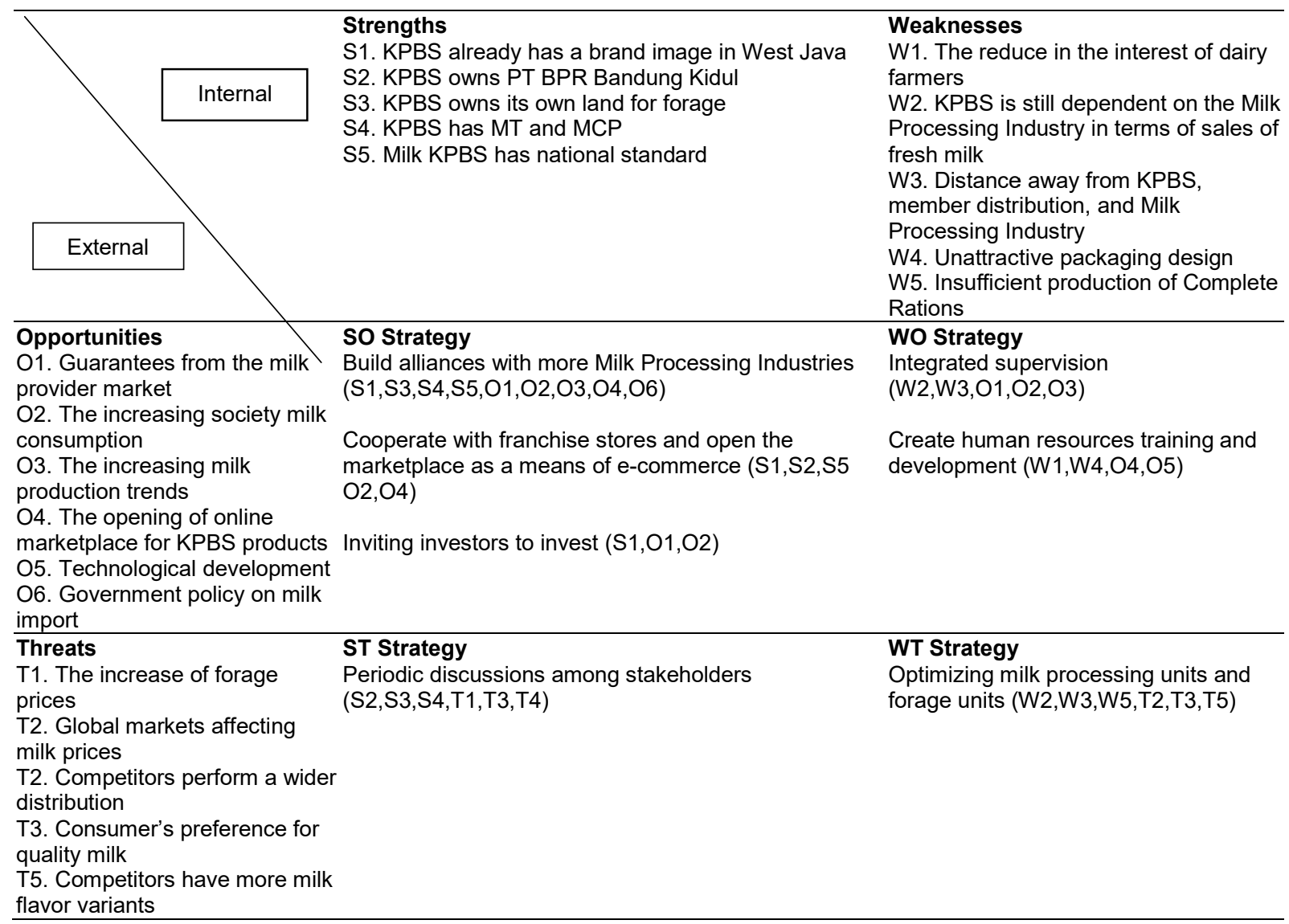

Determination of Priority Strategy. The determination of priority strategy is carried out using AHP method which is a method of making a priority sequence of various options so it can help to make a decision. There are seven alternative strategies generated from the previous SWOT analysis.

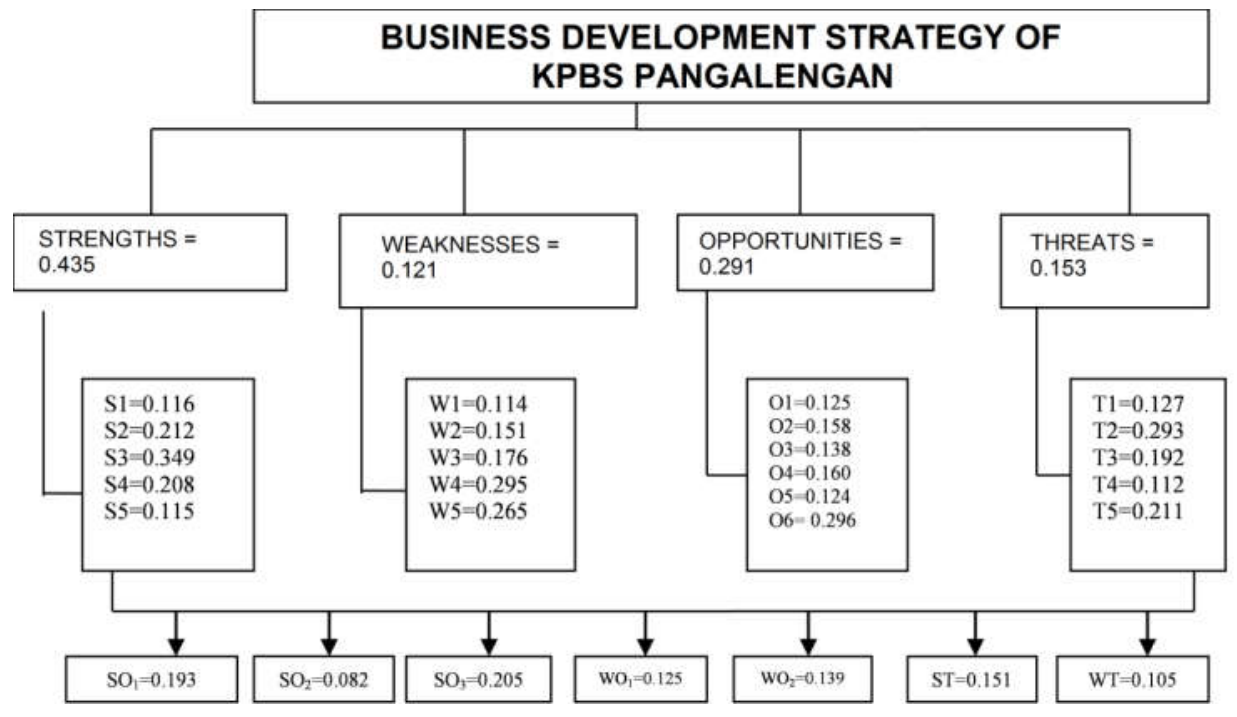

Figure 2 - AHP Hierarchy of KPBS Pangalengan

The hierarchy used in AHP consists of three levels: objectives to be achieved, criteria to be considered, and strategies used to achieve goals. The AHP hierarchy of KPBS can be seen in Figure 3. Then, the priority strategy results can be seen in Table 7. 
Table 7 - Strategy Weight and Priority of KPBS Business Development

\begin{tabular}{|c|c|c|c|}
\hline Strategy & Description & Weight & Rank \\
\hline $\mathrm{SO}_{3}$ & Inviting the investors to make investment & 0.205 & 1 \\
\hline $\mathrm{SO}_{1}$ & Building alliances with more Milk Processing Industry & 0.193 & 2 \\
\hline ST & Conducting periodic discussions among stakeholders & 0.151 & 3 \\
\hline $\mathrm{WO}_{2}$ & Creating human resources training and development & 0.139 & 4 \\
\hline $\mathrm{WO}_{1}$ & Conducting integrated supervision & 0.125 & 5 \\
\hline WT & Optimizing milk processing units and forage units & 0.105 & 6 \\
\hline $\mathrm{SO}_{2}$ & Cooperating with franchise stores and opening the marketplace as a means of e-commerce & 0.082 & 7 \\
\hline
\end{tabular}

The first strategy rank is inviting the investors to make investment with the weight of 0.205. KPBS requires a lot of capital to conduct expansion activities such as adding machine technology for processing units, establishing several buildings for dairy processing, and adding feed processing technology. The second strategy rank is building alliances with more Milk Processing Industry with the weight of 0.193 . In addition to be the biggest consumers of cooperatives, stock farmers are expected to get assistance on milk production management, improvement of production facilities and infrastructure, quality improvement and productivity that can directly affect the increase of milk production and welfare of stock farmers. The third strategy rank is conducting periodic discussions among stakeholders with the weight of 0.151 . The existence of this discussion aims to alert the stakeholders that they have a dependence on each other in running a business. Thus, this will facilitate problem solving because each stakeholder has a specific role. The fourth strategy rank is creating human resources training and development with the weight of 0.139 . KPBS conducts professional training so that KPBS members have skills above the average.

The fifth strategy rank is conducting integrated supervision with the weight of 0.125 . The supervisor must be able to analyze the existing problems so that it can become input for the next KPBS program. The sixth strategy rank is optimizing milk processing units and forage units with the weight of 0.105 . Milk yield can be processed and provide added value so it can be marketed at a higher price than unprocessed fresh milk. Complete rations, as forage products, can be sold in a bigger number. The seventh strategy rank is cooperating with franchise stores and opening the marketplace as a means of e-commerce with the weight of 0.082 . Expansion strategy needs to be carried out by KPBS because KPBS already has several advantages such as brand image that has been created in West Java and milk that has a national standard (SNI).

Managerial Implications. Step that needs to be done to convince investors to cooperate is to discuss the strong potential related with dairy farm business. Professionally, the KPBS also need to inform the possibility of business failure, considering that the business is a highrisk business. KPBS is expected to attract other Milk Processing Industry such as PT Ajinomoto Calpis Beverage Indonesia, PT Puri Purnama Delodyeh, PT Danone, and many more industries which produce milk derivative products. This cannot be separated from the assistance of the Livestock Service Office and the Cooperative Office of Small and Medium Enterprises where the two agencies are more experienced in the negotiations.

The neutral role of the academic institution is needed, especially the agriculture institution such as Bogor Agricultural University as a facilitator for the seminar to run smoothly. Stakeholders who can be invited to the event are the Indonesian Milk Cooperatives Association, Milk Processing Industry, and the Ministry of Agriculture. Associated with the transfer of information to the breeders, absolutely, it needs to be held training to increase the supervisory skills. Increasing the number of supervisors is also needed considering the distance between members in the KPBS in order to increase the frequency of counseling.

Local stock farmers can learn from those who have successfully developed a business and learn tips and tricks and appropriate technology that can be used in carrying out stock farming. Steps that can be taken to optimize the milk processing unit is to form a research and development unit specifically to analyze the prospects of dairy products either from the correct way of processing and how is the marketing of manufactured products. The existence of KPBS products in franchise stores such as Indomaret and Alfamart will make more people 
know about KPBS products. This method is one effort to improve the competitiveness of farmers under the auspices of cooperatives to get other business opportunities.

\section{CONCLUSION AND SUGGESTIONS}

The result of the sequence of strategies leads to business development that is by inviting the investors to make investment in KPBS and building alliances with more Milk Processing Industry. Both strategies will motivate the stock farmers to be more enthusiastic in the maintenance process until the production process. Thus, it can improve the competitiveness of the stock farmers. After performing these two strategies, KPBS can run the following four strategies: conducting periodic discussions among stakeholders, creating human resources training and development, conducting integrated supervision, optimizing milk processing units, and resuming expansion strategy by cooperating with franchise stores and e-commerce.

Supposedly, KPBS always pay attention to the weaknesses and threats they face by increasing the strength and exploit the existing opportunities. KPBS also needs to develop Resource and Development to create new products and increase product sales. Capital owned by KPBS should be used for productive business activity by conducting business development to franchise, e-commerce, and management of milk production. Government policies related to the development of cooperatives also need to be carried out appropriately.

\section{REFERENCES}

1. Anggraeni, A. N. N. E. K. E. (2012). Perbaikan genetik sifat produksi susu dan kualitas susu sapi Friesian Holstein melalui seleksi. Wartazoa, 22, 1-11.

2. Asmara A, Purnamadewi YL, \& Lubis D. (2016). Keragaan produksi susu dan efisiensi peternak sapi perah rakyat di Indonesia. Journal of Management and Agribusiness.13(1):1-4

3. Boediyana, T. (2008). Menyongsong agribisnis persusuan yang prospektif di Tanah Air. Majalah Trobos.

4. David. (2009). Manajemen strategis: Konsep. Edisi 13. Jakarta (ID): Salemba Empat.

5. Dong, F. (2006). The outlook for Asian dairy markets: The role of demographics, income, and prices. Food Policy, 31(3), 260-271.

6. Douphrate, D. I., Hagevoort, G. R., Nonnenmann, M. W., Lunner Kolstrup, C., Reynolds, S. J., Jakob, M., \& Kinsel, M. (2013). The dairy industry: a brief description of production practices, trends, and farm characteristics around the world. Journal of agromedicine, 18(3), 187-197.

7. Hendrojogi. (2007). Koperasi. Asas-asas, Teori dan Praktik. Edisi 4. Jakarta (ID): Raja Grafindo Persada.

8. Kumar, A., Shinoj, P., \& Jee, S. (2013). Do dairy co-operatives enhance milk production, productivity and quality? Evidences from the Indo-Gangetic Plain of India. Indian Journal of Agricultural Economics, 68(3), 457-468.

9. Mandaka, S., \& Hutagaol, M. P. (2016). Analisis fungsi keuntungan, efisiensi ekonomi dan kemungkinan skema kredit bagi pengembangan skala usaha peternakan sapi perah rakyat di Kelurahan Kebon Pedes, Kota Bogor. Jurnal Agro Ekonomi, 23(2), 191-208.

10. Morey, P. (2011). Indonesia dairy industry development. International Finance Corporation.

11. Mubyarto, Ramli, R., Ismawan, B., Baswir, R., Pasaribu, B., Suma, A., Sinulingga, R., Sukarsa, I.M., Mursidi, N., Muhammad, F. (2014). Ekonomi Kerakyatan. Jakarta: Lembaga Suluh Nusantara.

12. Sirait, B. (2009). Analisis pengaruh program dinas koperasi dan UKM terhadap perkembngan koperasi, usaha mikro kecil dan menengah (UMKM) di provinsi Sumatera Utara. [tesis]. USU. 